\title{
Front Matter: Volume 9932
}

, "Front Matter: Volume 9932," Proc. SPIE 9932, Carbon Nanotubes, Graphene, and Emerging 2D Materials for Electronic and Photonic Devices IX, 993201 (5 December 2016); doi: 10.1117/12.2258413

SPIE Event: SPIE Nanoscience + Engineering, 2016, San Diego, California, United SPIE. States 


\title{
PROCEEDINGS OF SPIE
}

\section{Carbon Nanotubes, Graphene, and Emerging 2D Materials for Electronic and Photonic Devices IX}

\author{
Manijeh Razeghi \\ Maziar Ghazinejad \\ Can Bayram \\ Jae Su Yu \\ Editors
}

28-31 August 2016

San Diego, California, United States

Sponsored and Published by

SPIE 
The papers in this volume were part of the technical conference cited on the cover and title page. Papers were selected and subject to review by the editors and conference program committee. Some conference presentations may not be available for publication. Additional papers and presentation recordings may be available online in the SPIE Digital Library at SPIEDigitallibrary.org.

The papers reflect the work and thoughts of the authors and are published herein as submitted. The publisher is not responsible for the validity of the information or for any outcomes resulting from reliance thereon.

Please use the following format to cite material from these proceedings:

Author(s), "Title of Paper," in Carbon Nanotubes, Graphene, and Emerging 2D Materials for Electronic and Photonic Devices IX, edited by Manijeh Razeghi, Maziar Ghazinejad, Can Bayram, Jae SU Yu, Proceedings of SPIE Vol. 9932 (SPIE, Bellingham, WA, 2016) Six-digit Article CID Number.

ISSN: 0277-786X

ISSN: 1996-786X (electronic)

ISBN: 9781510602557

ISBN: 9781510602564 (electronic)

Published by

SPIE

P.O. Box 10, Bellingham, Washington 98227-0010 USA

Telephone +1 3606763290 (Pacific Time) · Fax +1 3606471445

SPIE.org

Copyright @ 2016, Society of Photo-Optical Instrumentation Engineers.

Copying of material in this book for internal or personal use, or for the internal or personal use of specific clients, beyond the fair use provisions granted by the U.S. Copyright Law is authorized by SPIE subject to payment of copying fees. The Transactional Reporting Service base fee for this volume is $\$ 18.00$ per article (or portion thereof), which should be paid directly to the Copyright Clearance Center (CCC), 222 Rosewood Drive, Danvers, MA 01923. Payment may also be made electronically through CCC Online at copyright.com. Other copying for republication, resale, advertising or promotion, or any form of systematic or multiple reproduction of any material in this book is prohibited except with permission in writing from the publisher. The CCC fee code is 0277-786X/16/\$18.00.

Printed in the United States of America.

Publication of record for individual papers is online in the SPIE Digital Library.

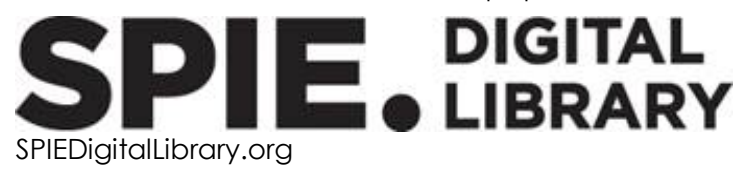

Paper Numbering: Proceedings of SPIE follow an e-First publication model. A unique citation identifier (CID) number is assigned to each article at the time of publication. Utilization of CIDs allows articles to be fully citable as soon as they are published online, and connects the same identifier to all online and print versions of the publication. SPIE uses a six-digit CID article numbering system structured as follows:

- The first four digits correspond to the SPIE volume number.

- The last two digits indicate publication order within the volume using a Base 36 numbering system employing both numerals and letters. These two-number sets start with 00, 01, 02, 03, 04, 05 , $06,07,08,09,0 A, 0 B \ldots$. OZ, followed by 10-1Z, 20-2Z, etc. The CID Number appears on each page of the manuscript. 


\title{
Contents
}

\author{
$\checkmark \quad$ Authors \\ vii Conference Committee
}

\section{DEVICES I}

993204 Carbon nanotube: nanodiamond Li-ion battery cathodes with increased thermal conductivity [9932-3]

SYNTHESIS, CHARACTERIZATION, AND MODELING I

993207 Mapping electromagnetic dualities via quantum decoherence measurements in 2D materials (Invited Paper) [9932-6]

993209 Ultra-low frequency Raman spectroscopy of SWNTs under high pressure [9932-9]

$99320 \mathrm{~A}$ Fabrication and characterization of polycaprolactone-grapheme powder electrospun nanofibers [9932-29]

SYNTHESIS, CHARACTERIZATION, AND MODELING II

9932 OD Classical analogues of Gilmore-Perelomov coherent states [9932-12]

9932 OE Graphene under a few-cycle circularly polarized optical field: ultrafast interferometry and Berry phase manifestation [9932-13]

\section{DEVICES II}

9932 OG Manufacturing carbon nanofiber electrodes with embedded metallic nanoparticles using block copolymers templates [9932-15]

$9932 \mathrm{OH} \quad$ Graphene-enhanced thermal interface materials for heat removal from photovoltaic solar cells [9932-16]

9932 Ol Graphene oxide- $\mathrm{MnO}_{2}$ nanocomposite for supercapacitor application [9932-17]

DEVICES III

$99320 Q \quad$ Optoelectronic mixing on CVD graphene up to 30 Gigahertz: analysis at high electrostatic doping [9932-24]

9932 OS Energy dynamics of solar thermionic power conversion with emitter of graphene [9932-26] 
Proc. of SPIE Vol. $9932993201-4$

Downloaded From: https://www.spiedigitallibrary.org/conference-proceedings-of-spie on 26 Apr 2023 Terms of Use: https://www.spiedigitallibrary.org/terms-of-use 


\section{Authors}

Numbers in the index correspond to the last two digits of the six-digit citation identifier (CID) article numbering system used in Proceedings of SPIE. The first four digits reflect the volume number. Base 36 numbering is employed for the last two digits and indicates the order of articles within the volume. Numbers start with $00,01,02,03,04,05,06,07,08,09,0 A, 0 B . .0 Z$, followed by 10-1Z, 20-2Z, etc.

Apalkov, Vadym, OE

Balandin, Alexander A., $04, \mathrm{OH}$

Bezencenet, O., OQ

Ceretti, Elisabetta, $0 \mathrm{~A}$

Chandra Bose, A., 01

De, Dilip K., OS

Gamalath, D., $\mathrm{OH}$

Ghazinejad, Maziar, OA, OG

Ginestra, Paola, OA

Heremans, J. J., 07

Hernandez, E., $\mathrm{OH}$

Holmberg, Sunshine, OG

Koochaki Kelardeh, Hamed, OE

Larat, C., OQ

Le Priol, C., 07

Lee, Eungiee, 04

Legagneux, P., OQ

Madou, Marc, OA, OG

Mazellier, J.-P., OQ

Molin, S., OQ

Montanaro, A., OQ

Mzali, S., OQ

Olawole, Olukunle C., OS

Oyedepo, Sunday O., OS

P., Muhammed Shafi, Ol

Quirke, N., 09

Ren, S. L., 07

Rodríguez-Lara, B. M., OD

Saadah, $\mathrm{M}$., $\mathrm{OH}$

Salgado, Ruben, 04

Santos, M. B., 07

Shen, Y., 09

Shevchenko, Elena V., 04

Stockman, Mark I., OE

Villanueva Vergara, Liliana, OD

Vishal, Jose K., Ol

Xie, Yuantao, 07

Zerulla, D., 09 
Proc. of SPIE Vol. $9932993201-6$

Downloaded From: https://www.spiedigitallibrary.org/conference-proceedings-of-spie on 26 Apr 2023 Terms of Use: https://www.spiedigitallibrary.org/terms-of-use 


\section{Conference Committee}

Symposium Chairs

Harry A. Atwater, California Institute of Technology (United States)

Nikolay I. Zheludev, Optoelectronics Research Centre

(United Kingdom) and Nanyang Technological University

(Singapore)

Symposium Co-chairs

David L. Andrews, University of East Anglia (United Kingdom)

James G. Grote, Air Force Research Laboratory (United States)

\section{Conference Chairs}

Manijeh Razeghi, Northwestern University (United States)

Maziar Ghazinejad, California State University, Fresno (United States)

Can Bayram, University of Illinois at Urbana-Champaign (United States)

Jae Su Yu, Kyung Hee University (Korea, Republic of)

\section{Conference Program Committee}

Seunghyun Baik, Sungkyunkwan University (Korea, Republic of)

Paolo Bondavalli, Thales Research \& Technology (France)

Markus Buehler, Massachusetts Institute of Technology (United States)

Costel-Sorin Cojocaru, Ecole Polytechnique (France)

Ertugrul Cubukcu, University of Pennsylvania (United States)

Christos D. Dimitrakopoulos, University of Massachusetts Amherst (United States)

Charles M. Falco, College of Optical Sciences, The University of Arizona (United States)

Talia Gershon, IBM Thomas J. Watson Research Center (United States)

Kenji Hata, National Institute of Advanced Industrial Science and

Technology (Japan)

Mark C. Hersam, Northwestern University (United States)

Seong Chan Jun, Yonsei University (Korea, Republic of)

Jeehwan Kim, IBM Thomas J. Watson Research Center (United States)

Horacio Lamela Rivera, Universidad Carlos III de Madrid (Spain)

Seung Hee Lee, Chonbuk National University (Korea, Republic of)

Young Hee Lee, Sungkyunkwan University (Korea, Republic of)

Xiuling Li, University of Illinois at Urbana-Champaign (United States)

Annick Loiseau, ONERA (France) 
Jean-Pierre Luberton, University of Illinois at Urbana-Champaign (United States)

Masud Mansuripur, College of Optical Sciences, The University of Arizona (United States)

Ryan McClintock, Northwestern University (United States)

William I. Milne, University of Cambridge (United Kingdom)

Sedat Nizamoglu, Koç University (Turkey)

Cengiz S. Ozkan, University of California, Riverside (United States)

Hongsik Park, Kyungpook National University (Korea, Republic of)

Philip W. T. Pong, The University of Hong Kong (Hong Kong, China)

Fengnian Xia, Yale University (United States)

Wenjuan Zhu, University of Illinois at Urbana-Champaign

(United States)

\section{Session Chairs}

1 Devices I

Maziar Ghazinejad, California State University, Fresno (United States)

2 Synthesis, Characterization, and Modeling I

Maziar Ghazinejad, California State University, Fresno (United States)

3 Synthesis, Characterization, and Modeling II

Jean J. Heremans, Virginia Polytechnic Institute and State University (United States)

4 Devices II

James Butler, Euclid Technology Laboratories, LLC (United States)

5 Synthesis, Characterization, and Modeling III

Maziar Ghazinejad, California State University, Fresno (United States)

6 Devices III

Sunny Holmberg, University of California, Irvine (United States) 